\title{
SISTEM INFORMASI RAWAT JALAN PASIEN BPJS PADA RUMAH SAKIT
}

\author{
Fernando B Siahaan \\ Program Studi Manajemen Informatika \\ AMIK BSI Jakarta \\ Jl. RS Fatmawati No. 24 Jakarta, \\ Indonesia \\ E-mail: fernando.fbs@bsi.ac.id
}

\author{
Dede Awalludin \\ Program Studi Sistem Informasi \\ STMIK Nusa Mandiri Jakarta \\ Jl. Damai No. 8 Warungjati Barat \\ Indonesia \\ E-mail:adew346@gmail.com
}

\begin{abstract}
Registration of outpatient BPJS at Rumah Sakit Islam Jakarta Pondok Kopi in its operational condition is obstacles that is a long time in the registration process due to the large volume of patient visit each day. So it takes a cient server based information system that can support so as to produce better service. The purpose of this study was to provide an alternative model of outpatient administration of BPJS patients. The method used in this study waterfall with stages analyze the needs of software, design, code generation, testing and support. The discussion by designing the system in the form of usecase diagrams, activity diagrams, sequence diagrams and ERD. The conclusion of this study computerized system made for RSIJPK can help overcome the problems in the process of registration of patients so that the time required to be faster.

This electronic document is a "live" template. The various components of your paper [title, text, heads, etc.] are already defined on the style sheet, as illustrated by the portions given in this document. (Abstract)
\end{abstract}

Keywords-component; Information system; waterfale; software)

\section{PENDAHUUAN}

Sesuai Program Pemerintah UU.No.40 tahun 2004 tentang Program Jaminan Kesehatan Nasional (JKN) yaitu program kesehatan nasional yang penerapannya menggunakan sistem asuransi maka seluruh masyarakat Indonesia akan di jamin kesehatannya dan kepesertaannnya bersifat wajib termasuk masyarakat yang tidak mampu karena metode pembiayaan kesehatannya di tanggung oleh pemerintah dan iuran rakyat. Sistem asuransi ini di kelola oleh Badan Penyelenggara Jaminan Sosial (BPJS).

RSUD Kraton Pekalongan Jawa Tengah merupakan salah satu Badan Layanan Umum Daerah (BLUD) yang bergerak dalam bidang pelayanan kesehatan khususnya bagi masyarakat kabupaten pekalongan dan sekitarnya. Salah satu layanan yang ada adalah pelayanan berobat rawat jalan yang dalam operasionalnya banyak mengalami hambatan dikarenakan volume kunjungan pasien yang besar tanpa didukung dengan alat bantu berupa sistem informasi berbasis komputer. Penelitian ini mencoba memberikan sebuah alternatif model administrasi rawat jalan dengan menggunakan sistem informasi dengan arsitektur aplikasi client/server yang dapat menghubungkan beberapa bagian yang terlibat dalam operasional rawat jalan. Metode pengembangan sistem yang digunakan adalah pendekatan pengembangan sistem terstruktur (structured approach). Dengan adanya sistem ini administrasi registrasi pasien, tindakan dan pemakaian alat kesehatan serta pelayanan resep dapat dibantu dengan menggunakan sistem, selanjutnya seluruh tagihan pasien dapat dengan mudah ditampilkan melalui menu kasir sebagai tagihan pasien yang berkunjung untuk berobat di instalasi rawat jalan. (Triwahyuni, 2013).

Rumah sakit Assakinah Mediak (RSAM) merupakan klinik umum dan rumah bersalin yang berdiri sejak tahun 2010 . Rumah sakit ini melayani pasien untuk berobat jalan yang dimulai dari proses pendaftaran pasien, registrasi, pemberian tindakan dan pencatatan rekam medis, pengambilan obat dan pembayaran. Permasalahan pada penelitian ini adalah jika dokumen rekam medis (RM) tidak ditemukan maka pasien dianggap tidak memiliki dokumen RM meskipun pasien sudah pernah berobat, sehingga dibuatkan yang baru. Hal ini yang menyebabkan terjadinya penumpukan data (redudansi) yang menyebabkan status pasien tidak diketahui apakah pasien lama/baru. Untuk membatu penyelesaian permasalahan tesebut dibutuhkan sistem informasi yang terintegrasi dari bagian pendaftaran sampai dengan pembayaran. Kesimpulan penelitian ini adalah sistem informasi rekam medis pasien dapat mempercepat proses pencarian data pasien sehingga tidak memunculkan kembali data yang bersifat ganda. Waktu pelayanan pasien menjadi lebih cepat sehingga mempercepat waktu tindakan dokter kepada pasien. Data rekam medis tersimpan dengan baik dan sewaktu-waktu diperlukan dapat diperoleh dengan mudah. (Lemantara \& Indrawati, 2015)

Rumah Sakit Islam Jakarta Pondok Kopi (RSIJPK) sebagai salah satu fasilitas pemberi pelayanan kesehatan, telah ikut serta dalam penerapan program JKN. Setiap harinya RSIJPK khususnya pelayanan rawat jalan BPJS, melayani rata-rata 400 peserta BPJS dan menimbulkan banyak permasalahan diantaranya antrian yang panjang di loket jaminan BPJS dan loket pendaftaran rawat jalan BPJS. keluhan dari pasien tentang lamanya waktu yang dibutuhkan untuk melakukan proses pendaftaran hingga mendapatkan pelayanan dokter perlu ditanggapi manajemen rumah sakit secara positip. oleh karena itu dibutuhkan sistem yang mampu untuk mensoluiskan permasalahan tersebut. Prosedur administrasi yang sederhana, mudah dan cepat merupakan salah satu peningkatan pelayanan kepada pasien. Pelayanan pertama dari meja pendaftaran pasien sangat perlu diperhatikan, semakin cepat dalam pelayanan pendaftaran rawat jalan pasien baik pasien baru atau pasien 
lama akan berpengaruh pada cepatnya layanan medis yang diinginkan oleh pasien atau konsumen RSIJPK.

Permasalahan pada penelitian ini adalah "Bagaimana cara mengatasi antrian pada loket jaminan dan pendaftaran pasien BPJS rawat jalan?" tujuan penelitian ini untuk memberikan model alternatif administrasi rawat jalan pasien BPJS.

\section{LANDASAN TEORI}

\section{Konsep Dasar Sistem Informasi)}

Sistem didefinisikan sebagai sekumpulan prosedur yang saling berkaitan dan saling terhubung untuk melakukan suatu tugas bersama-sama. Secara garis besar, sebuah sistem informasi terdiri atas tiga komponen utama. Ketiga komponen tersebut mencakup software, hardware, dan brainware (Pratama, 2014).

Informasi adalah data yang telah diklasifikasikan atau diolah atau diinterpretasikan untuk digunakan dalam proses pengambilan keputusan (Sutabri, 2012). Nilai dari informasi didasarkan atas sepuluh sifat, yaitu:

1) Mudah diperoleh, misal: Fatini menunjukan kemudahan dan kecepatan untuk memperoleh informasi kecepatanya dapat diukur, misalnya 1 menit versus 24 jam.

2) Luas dan lengkap, yaitu sifat ini menunjukan kelengkapan isi informasi. Hal ini tidak hanya mengenai volumenya akan tetapi juga mengenai keluaran informasinya.

3) Ketelitian, yaitu sifat ini berhubungan dengan kebebasan dari kesalahan keluaran informasi. Pada volume data yang besar biasanya terdapat dua jenis kesalahan, yaitu kesalahan pencatatan dan kesalahan perhitungan.

4) Kecocokan, yaitu sifat menunjukan seberapa baik keluaran informasi dalam hubungannya dengan permintan para pemakainya.

5) Ketepatan waktu, yaitu sifat ini berhubungan dengan waktu yang dilalui, yang lebih pendek dari siklus untuk mendapatkan informasi.

6) Kejelasan, sifat ini menunjukan kejelasan tingkat informasi. Informasi informasi hendaknya terbebas dari istilah-istilah yang tidak jelas.

7) Keluwesan, yaitu sifat ini berhubungan dengan apakah sistem informasi tersebut dapat digunakan untuk membuat lebih dari satu keputusan, tetapi juga apakah dapat digunakan untuk lebih dari satu orang pengambil keputusan.

8) Dapat dibuktikan, sifat ini menunjukan sejauh mana informasi itu dapat diuji oleh bebrapa pemakai hingga sampai didapatkan kesimpulan yang sama.

9) Tdak ada prasangka, sifat ini berhubungan dengan ada tridaknya keinginan untuk mengubah informasi tersebut guna mendapatkan kesimpulan yang telah diarahkan sebelumnya.

10)Dapat diukur, sifat ini menunjukan hakikat informasi yang dihasilkan oleh sistem informasi formal. Meskipun kabar angin, desas-desus, dugaan-dugaan, klenik, dan lainya juga sering dianggap sebagai informasi, namun hal-hal tersebut berada diluar lingkup pembahasan kita.
B. Model USDP (Unified Software Development Process) USDP merupakan Proses pengembangan sistem yang berkelanjutan, dimana masing-masing bagian dilakukan secara iteratif. Dalam hal ini USDP menggunakan diagramdiagram UML yang sesuai dengan fungsinya masingmasing. (Nugroho , 2010). Adapun kegunaan model-model lainnya adalah sebagai berikut:

\section{Model Analisis (Analysis)}

Model analisis memiliki 2 kegunaan, yaitu memperluas dan merinci definisi-definisi masing-masing use case.

2. Model Perancangan (Design)

Model perancangan mendefinisikan struktur stastis sistem seperti sub sistem, kelas-kelas, dan antarmuka-antarmuka dan hubungannya masing-masing dalam kerangka sistem atau perangkat lunak yang sedang dikembangkan.

\section{Model Implementasi (Implementation)}

Model implementasi memuat komponen-komponen (merepresentasikan kode-kode dalam bahasa pemrograman tertentu yang dipilih) dan melakukan pemetaan kelas-kelas ke komponen-komponen.

\section{Model Deployment}

Model deployment mendefinisikan simpul-simpul komputer secara fisik dan melakukan pemetaan masing-masing komponen ke setiap komputer yang ada.

\section{Model Pengujian (Testing)}

Model pengujian mendeskripsikan kasus-kasus dan peosedur-prosedur pengujian yang tujuannya adalah melakukan verivikasi terhadap perangkat lunak yang dihasilkan dengan cara melihat dan memastikan apakah masing-masing use case telah diimplementasikan dengan cara yang sesuai dengan fungsionalitas utama yang tercakup di dalamnya.

\section{UML (Unified Modeling Language)}

Beberapa literature menyebutkan bahwa UML menyediakan sembilan jenis diagram, yang lain menyebutkan delapan karena ada beberapa diagram yang digabung, misanya diagram komunikasi, diagram urutan dan diagram pewaktuan digabung menjadi diagram interaksi. (Widodo \& Herlawati, 2011)

Namun demikian model-model itu dapat dikelompokkan berdasarkan sifatnya yaitu statis atau dinamis. Jenis diagram itu antara lain:

\section{Diagram kelas (Class Diagram)}

Bersifat statis, Diagram ini memperlihatkan himpunan kelas-kelas, antarmuka-antarmuka, kolaborasi-kolaborasi, serta relasi-relasi. Diagram ini umum dijumpai pada pemodelan sistem berorientasi objek. Meskipun bersifat statis, sering pula diagram kelas memuat kelas-kelas aktif.

\section{Diagram paket (Package Diagram)}

Bersifat statis. Diagram ini memperlihatkan kumpulan kelas-kelas, merupakan bagian dari diagram komponen.

3. Diagram Use-case (Use-case Diagram)

Bersifat statis. Diagram ini memperlihatkan himpunan usecase dan aktor-aktor (suatu jenis khusus dari kelas). Diagram 
ini terutama sangat penting untuk mengorganisasi dan memodelkan perilaku suatu sistem yang dibutuhkan serta diharapkan pengguna.

4. Diagram interaksi dan Sequence (Sequence Diagram)

Bersifat dinamis. Diagram urutan adalah iterasiksi yang menekankan pada pengiriman pesan dalam suatu waktu tertentu.

\section{Diagram Komunikasi (Communication Diagram)}

Bersifat dinamis. Diagram sebagai pengganti diagram kolaborasi UML yang menekankan organisasi struktural dari objek-objek yang menerima serta mengirim pesan.

\section{Diagram Statechart (Statechart Diagram)}

Bersifat dinamis. Diagram status memperlihatkan keadaankeadaan pada sistem, memuat status (state), transisi, kejadian serta aktivitas.

\section{Diagram aktivitas (Activity Diagram)}

Bersifat dinamis. Diagram aktivitas adalah tipe khusus dari diagram status yang memperlihatkan aliran dari suatu suatu aktivitas ke aktivitas lainnya dalam suatu sistem. Diagram ini terutama penting dalam pemodelan fungsi-fungsi suatu sistem dan memberi tekanan pada aliran kendali antar objek.

8. Diagram komponen (Component Diagram)

Bersifat statis. Diagram komponen ini memperlihatkan organisasi serta kebergantungan sistem/perangkat lunak pada komponen-komponen yang telah ada sebelumnya.

\section{Diagram Deployment (Deployment Diagram)}

Bersifat statis. Diagram inimemperlihatkan konfigurasi saat aplikasi dijalankan (run-time). Memuat simpul-simpul beserta komponen-komponen yang di dalamnya.

Kesembilan diagram ini tidak mutlak harus digunakan dalam pengembangan perangkat lunak, semuanya dibuat sesuai kebutuhan. Pada UML dimungkinkan kita menggunakan diagram-diagram lainnya (misalnya Data Flow Diagram, Entity Relationship Diagram, dan sebagainya).

\section{Basis Data}

Basis Data adalah "Suatu komponen dalam sistem informasi dan tidak ada sistem informasi yang bisa dijalankan tanpa adanya basis data". Jadi pada intinya untuk meningkatkan kinerja perusahaan menggunakan aplikasi berbasis komputer maka basis data mutlak diperlukan. (Hidayatullah, 2014).

Beberapa pemanfaatan basis data antara lain:

1) Kepegawaian, untuk berbagi perusahaan yang memiliki banyak pegawai.

2) Pergudangan (inventori) dan penjualan, untuk perusahan manufaktur (pabrik), supermarket, apotek, dan lain lain.

3) Akuntansi, untuk Bank dan perusahaan-perusahaan yang melibatkan uang.

4) Reservasi, untuk hotel, pesawat, kereta api.

5) Catatan medik, untuk rumah sakit.

\section{E. Black Box Testing}

"Black Box Testing adalah tipe testing yang memperlakukan perangkat lunak yang tidak diketahui kinerja internalnya". Sehingga para tester memandang perangkat lunak seperti layaknya sebuah "kotak hitam" yang tidak penting dilihat isinya, tapi cukup dikenai proses testing di bagian luar ).

Menurut Rizky (2011:264), Beberapa keuntungan yang diperoleh dari jenis testing ini antara lain :

1. Anggota tim tester tidak harus dari seseorang yang memiliki kemampuan teknis di bidang pemograman.

2. Kesalahan dari perangkat lunak ataupun bug seringkali ditemukan oleh komponen tester yang berasal dari pengguna.

3. Hasil dari black box testing dapat memperjelas kontradiksi ataupun kerancuan yang mungkin timbul dari eksekusi sebuah perangkat lunak.

4. Proses testing dapat dilakukan lebih cepat dibandingkan white box testing

\section{Sistem Informasi Rumah Sakit}

Sistem informasi rumah sakit merupakan sistem informasi yang ditujukan bagi rumah sakit untuk memudahkan di dalam pengelolaan data-data terkait medis dan administrasi di rumah sakit menjadi informasi yang bermanfaat bagi pasien, masyarakat umum, dan pihak rumah sakit (Pratama, 2014). rumah sakit merupakan institusiyang multi produk, padat modal, padat karya, dan padat teknologi, sehingga memerlukan manajemen yang baik dalam pengelolaannya.

\section{METODE PENELITIAN}

Tahapan penelitian dalam pengembangan sistem ini adalah menggunakan model waterfall sebagai berikut:

1. Analisa Kebutuhan Software

Melakukan analisa untuk mengetahui kebutuhan sistem seperti inputan untuk pasien lama atau baru, kebutuhan output pembuatan slip jaminan dan pendaftaran yang diperlukan RSIJPK

\section{Desain}

Mendefinisikan proses kebutuhan sistem yang berkaitan dengan pengembangan aplikasi. Pada tahap ini ditentukan pemilihan teknologi yang akan diterapkan, baik berupa rancangan database dengan menggambarkan ERD (Entity Relationship Diagram) maupun desain interface menggunakan UML (Unified Modeling Language).

3. Code Generation

Tahap penerjemahan desain sistem yang telah dibuat kedalam bentuk perintah-perintah yang dimengerti komputer dengan menggunakan bahasa pemrograman VB.NET dan SQL.

4. Testing

Pada tahap ini penulis melakukan proses pengujian menggunakan black box testing untuk memastikan sistem yang telah dibuat sesuai dengan desain dan fungsi yang dapat digunakan.

\section{Maintenance}


Menjaga agar sistem dapat tetap berjalan untuk menghasikan produktifitas informasi yang baik dengan menggunakan peralatan hardware dan software.

Teknik pengumpulan data yang dipakai adalah

a. Observasi dengan melakukan pengamatan secara langsung terhadap proses kegiatan pendaftaran pasien rawat jalan yang terjadi sehingga mengetahui masalahmasalah pada proses pendaftaran pasien.

b. Wawancara dengan melakukan tanya jawab kepada pihak terkait seperti bagian pendaftaran tentang proses jaminan dan pendaftaran pasien BPJS instalasi rawat jalan RSIJPK.

c. Studi Pustaka dengan melakukan pencarian pada sumber-sumber data yang relevan dalam hal ini bukubuku, internet yang relevan dengan proses pendaftaran pasien di rumah sakit.

\section{HASIL DAN PEMBAHASAN}

Tahapan yang dilakukan pada identifikasi dan implementasi rancangan sistem adalah sebagai berikut:

1. Rancangan Sistem

1) Rancangan Usecase Diagram Mengelola Data Pasien.

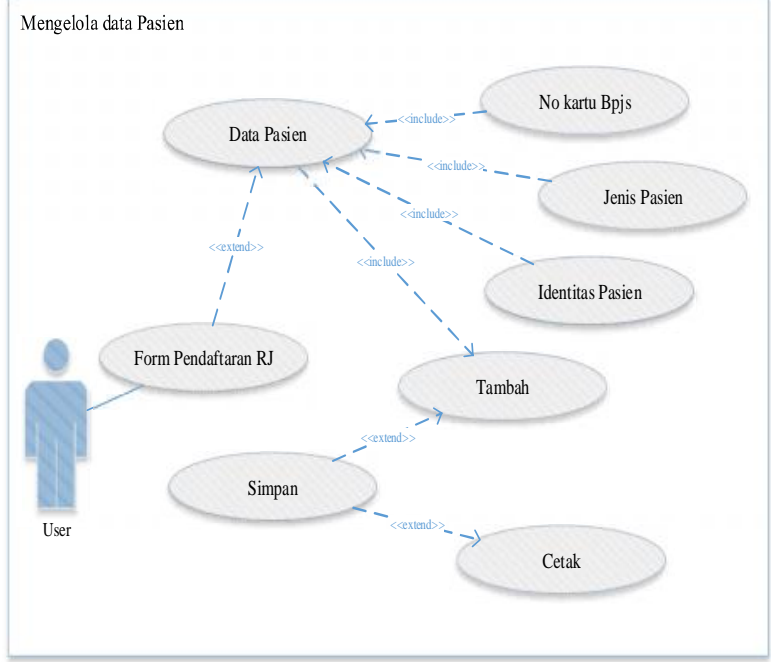

Gambar I.

Usecase Diagram Mengelola Data Pasien

2) Rancangan Usecase Diagram Mengelola Data Registrasi.

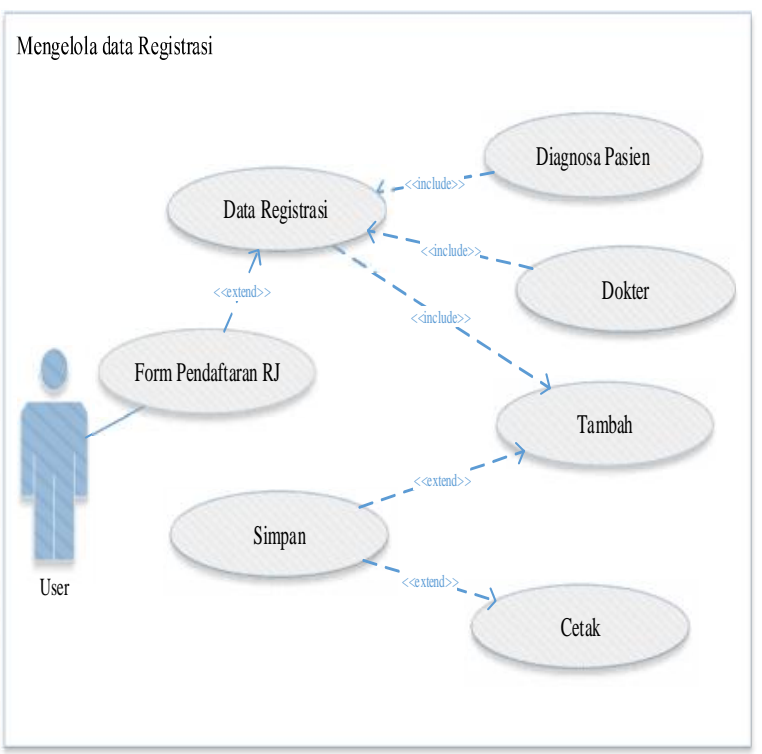

Gambar II.

Usecase Diagram Mengelola Data Registrasi

3) Rancangan Activity Diagram Pendaftaran Rawat Jalan Pasien.

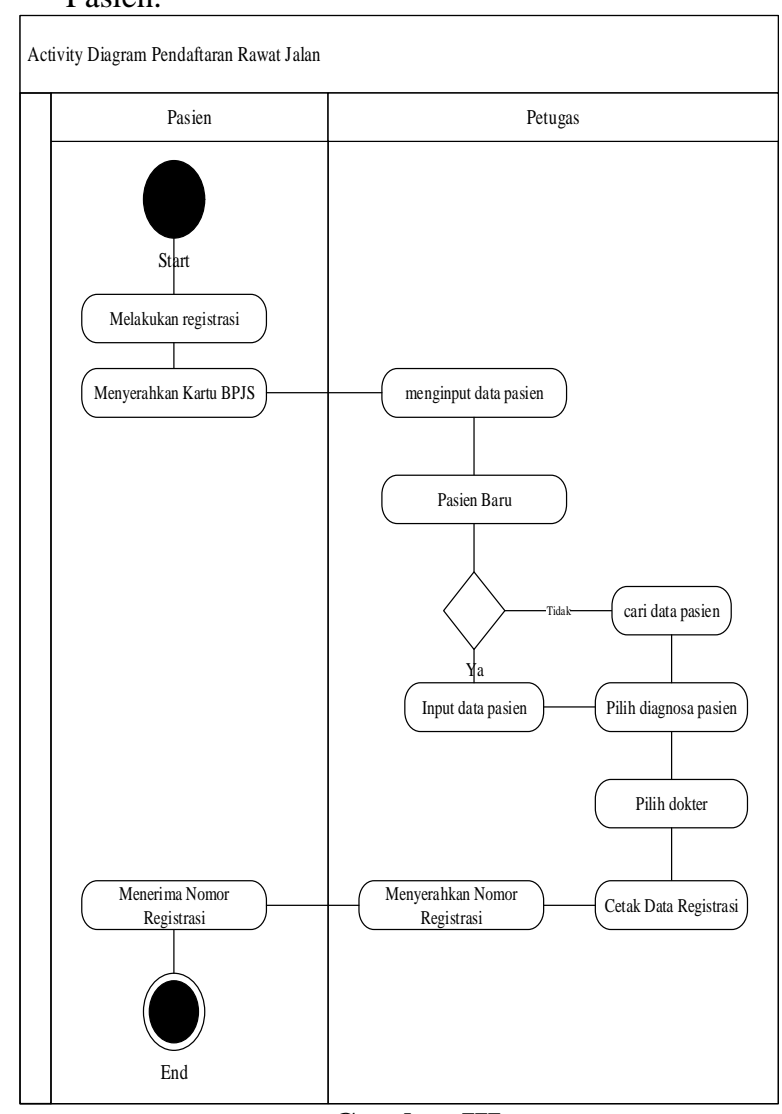

Gambar III.

Activity Diagram Pendaftaran Rawat Jalan Pasien 
4) Rancangan Activity Diagram Menambah Data User.

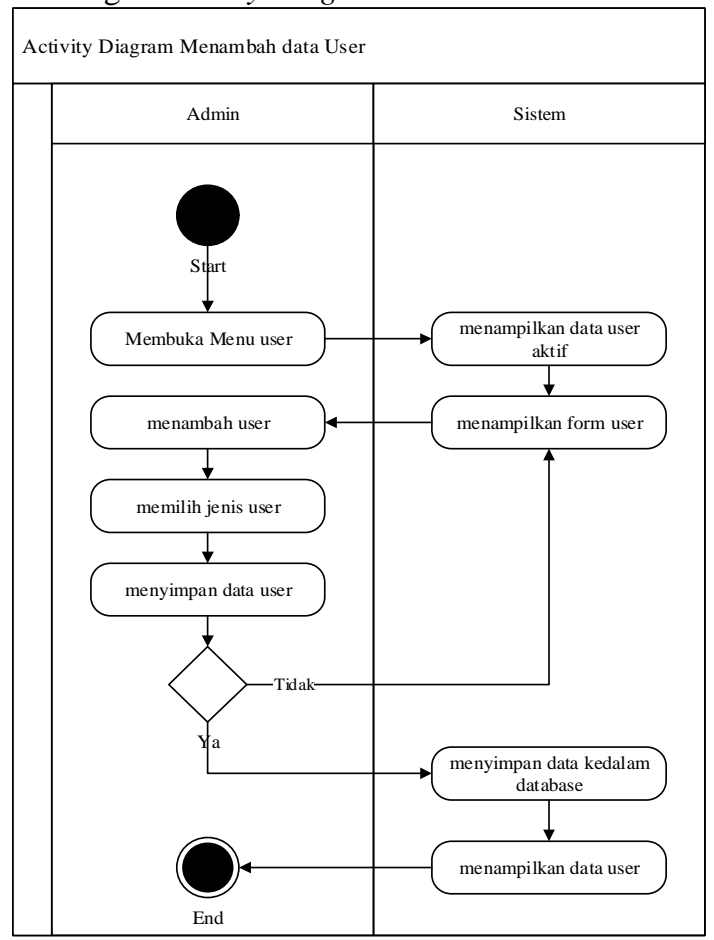

Gambar IV.

Activity Diagram Menambah Data User

5) Rancangan Sequence Diagram Pendaftaran Pasien Rawat Jalan.

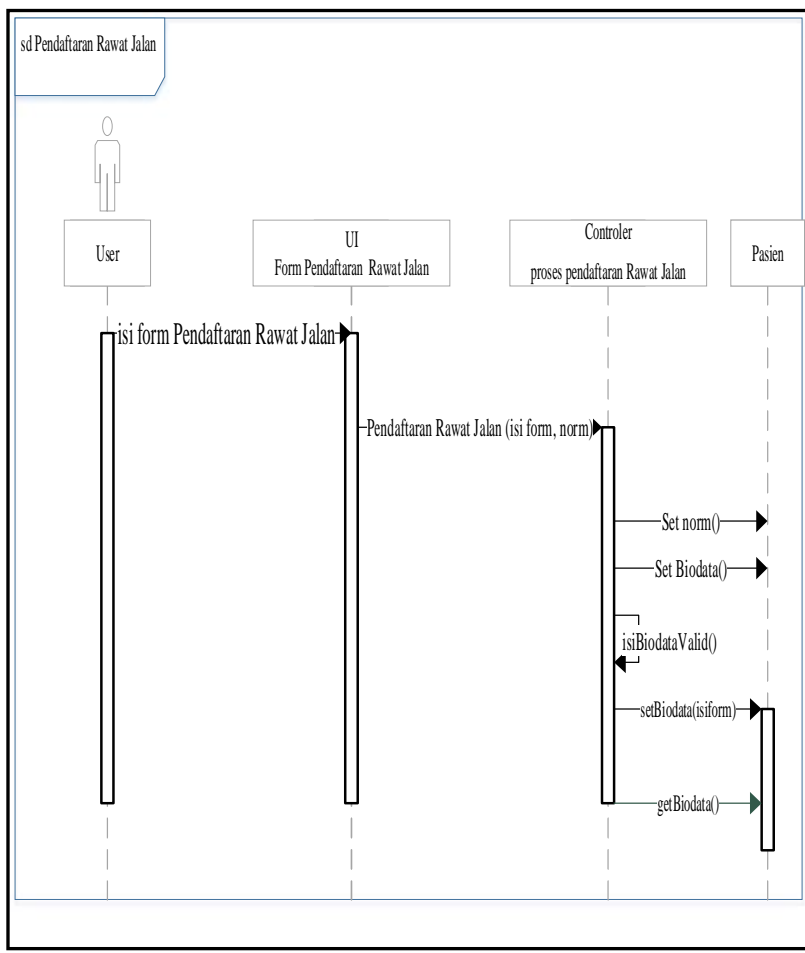

Gambar V.

Sequence Diagram Pendaftaran Pasien Rawat Jalan
2. Desain

Entity Relationship Diagram (ERD)

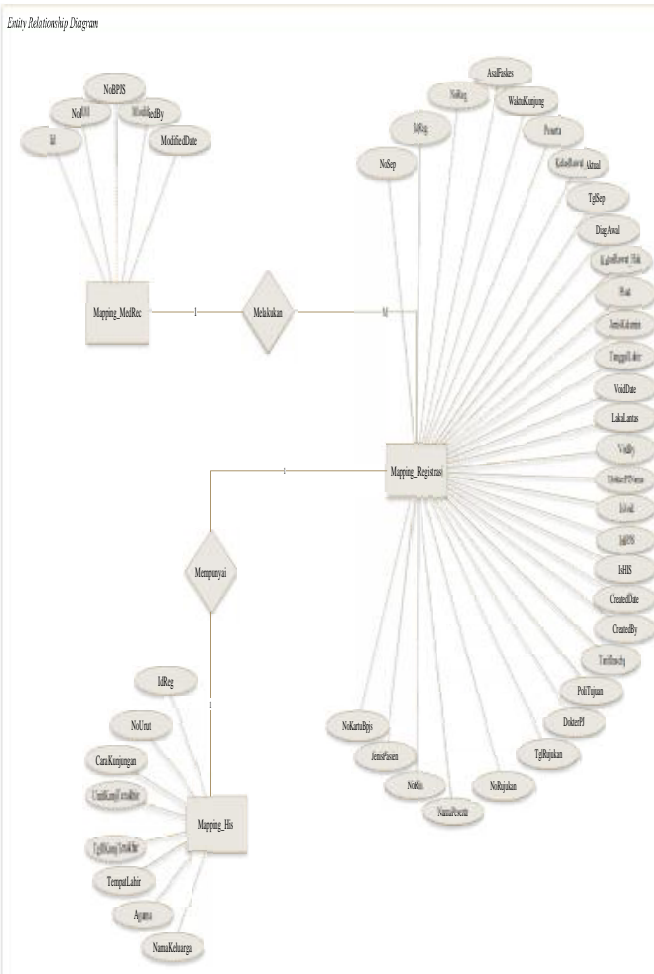

Gambar VI.

Entity Relationship Diagram

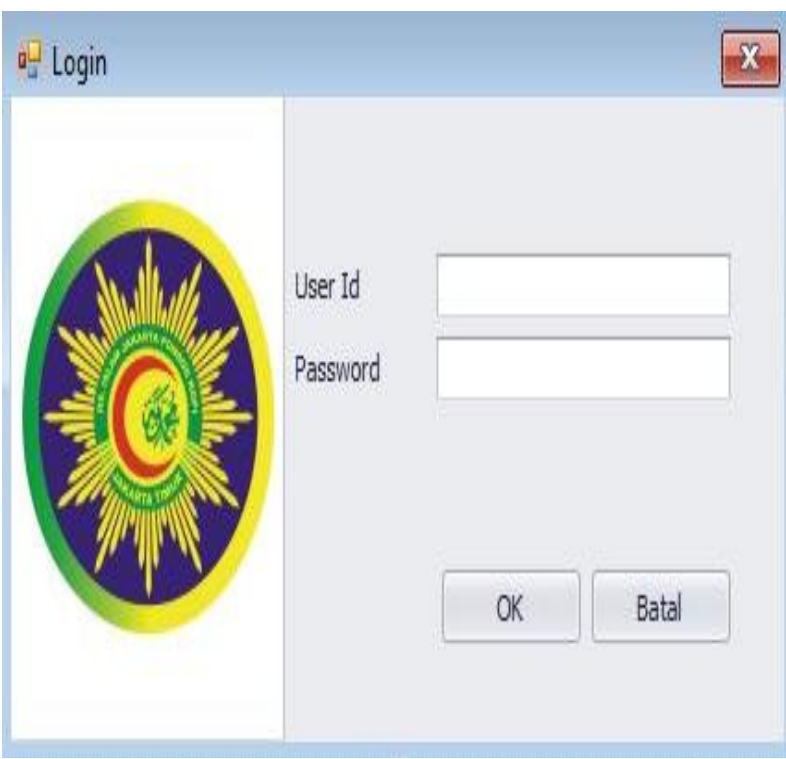

Gambar VII.

User Interface Login 


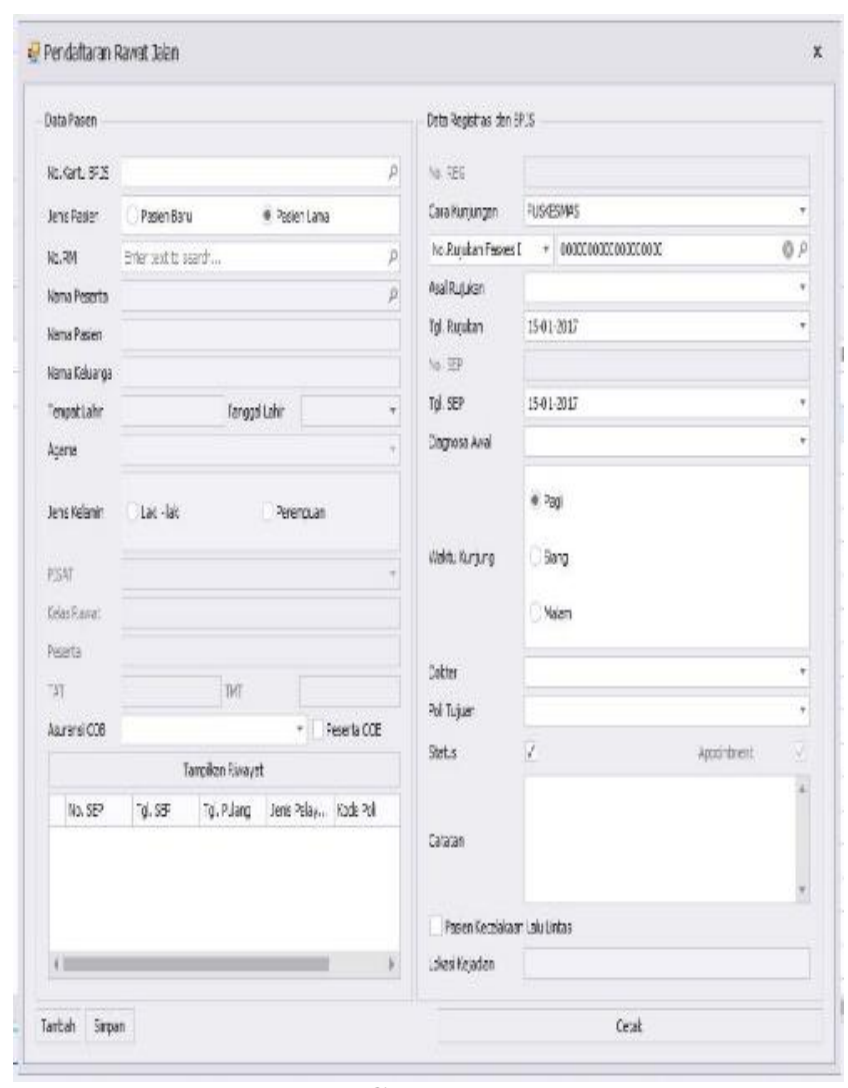

Gambar VIII.

User Interface Registrasi Pasien

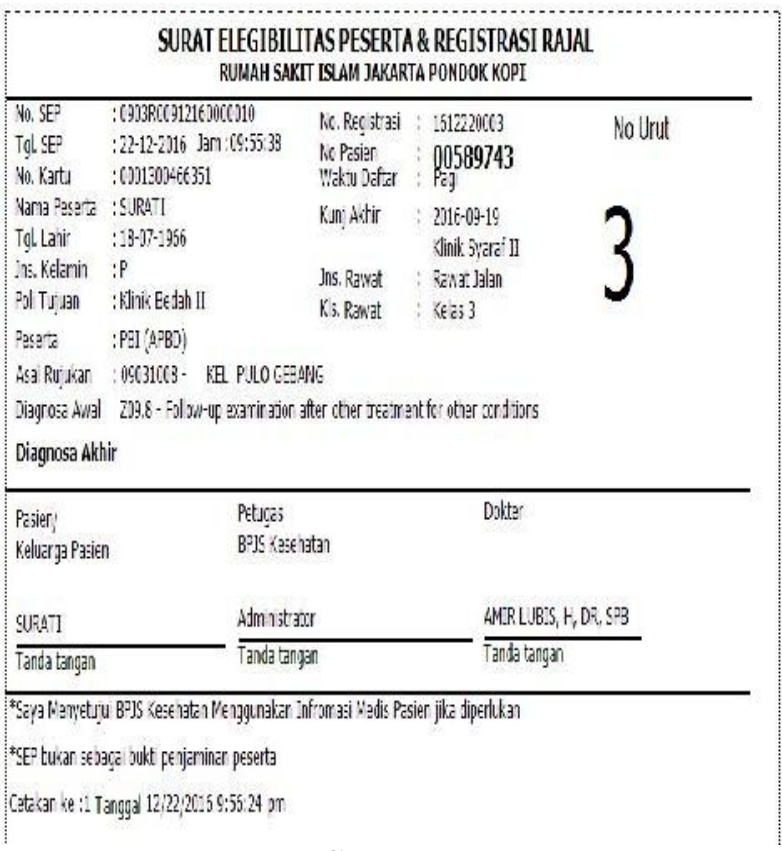

Gambar IX

Bukti Cetak Pendaftaran Pasien Rawat Jalan

\section{Code Generation}

Code generation yang digunakan pada menu utama namespace BPJSBridging \{

public partial class frmMain : DevExpress.XtraBars.Ribbon.RibbonForm

DataAccess.DataAccessLocalDb oDataAccess = new DataAccess.DataAccessLocalDb();

public frmMain()

\{

\}

InitializeComponent();

private void frmMain_Load(object sender, EventArgs e)

try

Program.cnstrHis = oDataAccess.generateConnectionString("his");

Program.cnstrBpjs = oDataAccess.generateConnectionString("bpjs"); frmLogin oLogin = new frmLogin();

oLogin.ShowDialog();

tmrCheckUser. Enabled $=$ true

catch (Exception ex)

throw ex;

(

private void btnLogout_ItemClick(object sender, ItemClickEventArgs e)

Program.userld = "";

Program.pass = "";

Program.userRole = "'";

frmLogin oLogin = new frmLogin();

oLogin.ShowDialog();

tmrCheckUser. Enabled $=$ true

\}

private void Rolelmplement()

btnAppSetting.Visibility = BarltemVisibility.Never;

btnUsers.Visibility = BarltemVisibility.Never

btnOutPatient.Visibility = BarltemVisibility.Never;

groupRegistration. Visible $=$ false;

switch (Program.userRole.ToLower())

case "admin":

groupRegistration. Visible $=$ true;

btnAppSetting.Visibility = BarltemVisibility.Always;

btnUsers.Visibility = BarltemVisibility.Always;

btnOutPatient.Visibility = BarltemVisibility.Always;

break;

case "rj":

groupRegistration. Visible = true;

btnOutPatient.Visibility = BarltemVisibility.Always

break;

default :

break;

private void tmrCheckUser_Tick(object sender, EventArgs e)

if (Program.userld == "'")

this.Close(); 


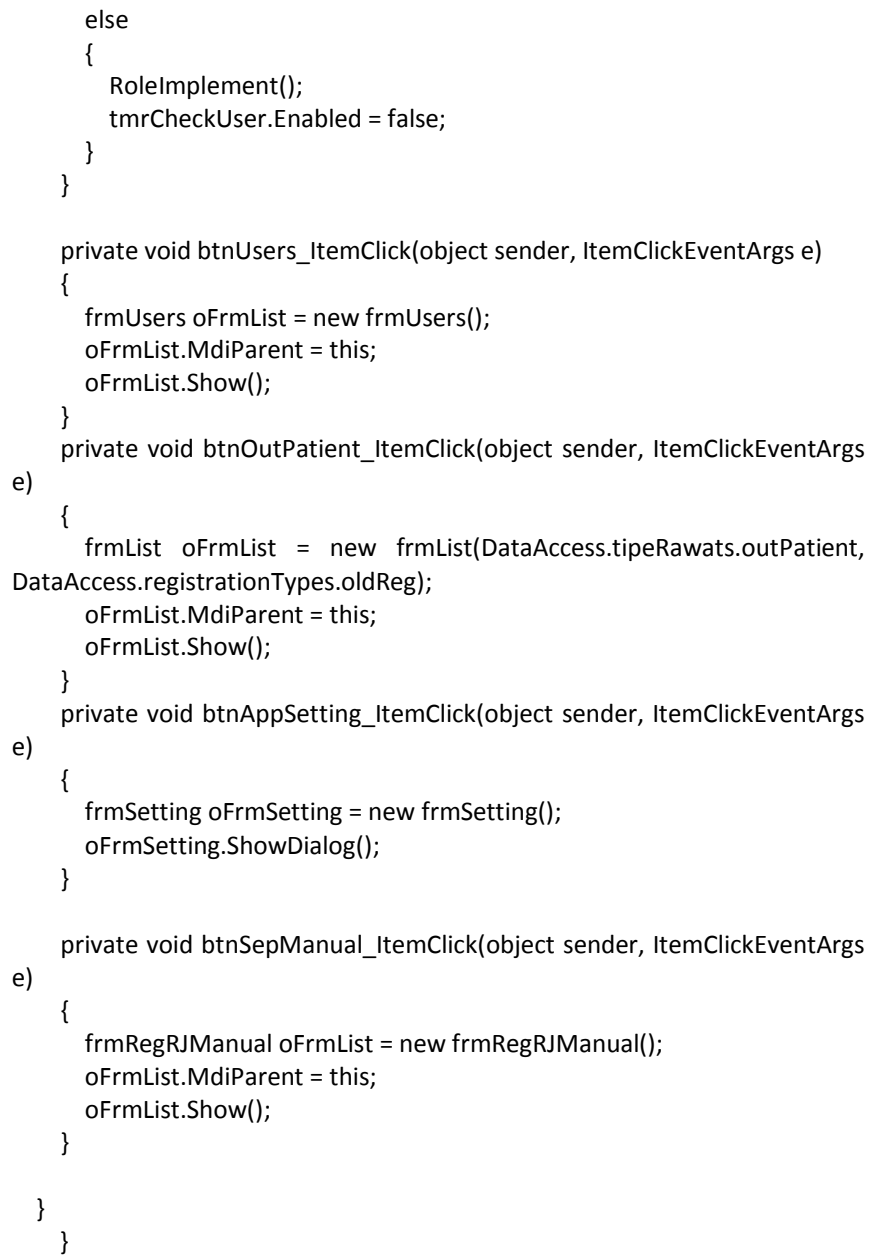

Metode blackbox Testing digunakan untuk menentukan apakah pearngkat lunak yang dibangun sudah sesuai dengan rancangan yang diharapkan

Tabel I.

Hasil Pengujian Black Box Testing Form Daftar Registrasi

\begin{tabular}{|c|c|c|c|c|c|}
\hline No & $\begin{array}{l}\text { Sekenario } \\
\text { Pengujian }\end{array}$ & Test Case & $\begin{array}{l}\text { Hasil yang } \\
\text { diharapkan }\end{array}$ & $\begin{array}{l}\text { Hasil } \\
\text { pengujian }\end{array}$ & $\begin{array}{l}\text { kesi } \\
\text { mpul } \\
\text { an }\end{array}$ \\
\hline 1 & $\begin{array}{l}\text { Cari data } \\
\text { pasien } \\
\text { berdasarkan } \\
\text { nomor kartu } \\
\text { BPJS }\end{array}$ & $\begin{array}{c}\text { Mengisi nomor } \\
\text { kartu BPJS } \\
\text { salah (0) }\end{array}$ & $\begin{array}{c}\text { Sistem akan } \\
\text { menampilkan } \\
\text { "Data yang } \\
\text { anda cari tidak } \\
\text { ada" }\end{array}$ & $\begin{array}{l}\text { "Data yang } \\
\text { anda cari } \\
\text { tidak ada" }\end{array}$ & Valid \\
\hline 2 & $\begin{array}{l}\text { Cari data } \\
\text { pasien } \\
\text { berdasarkan } \\
\text { nomor kartu } \\
\text { BPJS }\end{array}$ & $\begin{array}{c}\text { Mengisi no } \\
\text { kartu BPJS } \\
\text { benar } \\
(000004508615 \\
2)\end{array}$ & $\begin{array}{c}\text { Sistem akan } \\
\text { menampilkan } \\
\text { data registrasi } \\
\text { berdasarkan } \\
\text { nomor kartu } \\
\text { BPJS }\end{array}$ & $\begin{array}{c}\text { Data } \\
\text { registrasi } \\
\text { berdasarkan } \\
\text { nomor } \\
\text { kartu BPJS }\end{array}$ & Valid \\
\hline 3 & $\begin{array}{c}\text { Cari data } \\
\text { pasien } \\
\text { berdasarkan } \\
\text { nomor rekam } \\
\text { medis } \\
\end{array}$ & $\begin{array}{l}\text { Mengisi nomor } \\
\text { rekam medis } \\
\text { salah }(0)\end{array}$ & $\begin{array}{c}\text { Sistem akan } \\
\text { menampilkan } \\
\text { "Data yang } \\
\text { anda cari tidak } \\
\text { ada" }\end{array}$ & $\begin{array}{l}\text { "Data yang } \\
\text { anda cari } \\
\text { tidak ada" }\end{array}$ & Valid \\
\hline 4 & $\begin{array}{c}\text { Cari data } \\
\text { pasien } \\
\text { berdasarkan } \\
\text { nomor rekam } \\
\text { medis }\end{array}$ & $\begin{array}{l}\text { Mengisi no } \\
\text { rekam medis } \\
\text { benar } \\
(00569021)\end{array}$ & $\begin{array}{c}\text { Sistem akan } \\
\text { menampilkan } \\
\text { data registrasi } \\
\text { berdasarkan } \\
\text { nomor rekam } \\
\text { medis }\end{array}$ & $\begin{array}{c}\text { Data } \\
\text { registrasi } \\
\text { berdasarkan } \\
\text { nomor } \\
\text { rekam } \\
\text { medis }\end{array}$ & Valid \\
\hline
\end{tabular}

\begin{tabular}{|c|c|c|c|c|c|}
\hline 5 & $\begin{array}{c}\text { Cari data } \\
\text { pasien } \\
\text { berdasarkan } \\
\text { nomor SEP }\end{array}$ & $\begin{array}{c}\text { Mengisi nomor } \\
\text { SEP salah (0) }\end{array}$ & $\begin{array}{c}\text { Sistem akan } \\
\text { menampilkan } \\
\text { "Data yang } \\
\text { anda cari tidak } \\
\text { ada" }\end{array}$ & $\begin{array}{c}\text { "Data yang } \\
\text { anda cari } \\
\text { tidak ada" }\end{array}$ & Valid \\
\hline 6 & $\begin{array}{c}\text { Cari data } \\
\text { pasien } \\
\text { berdasarkan } \\
\text { nomor SEP }\end{array}$ & $\begin{array}{c}\text { Mengisi no } \\
\text { SEP benar } \\
(0903 \text { R00902 } \\
150000411)\end{array}$ & $\begin{array}{c}\text { Sistem akan } \\
\text { menampilkan } \\
\text { data registrasi } \\
\text { berdasarkan } \\
\text { nomor SEP }\end{array}$ & $\begin{array}{c}\text { Data } \\
\text { registrasi } \\
\text { berdasarkan } \\
\text { nomor SEP }\end{array}$ & Valid \\
\hline 7 & $\begin{array}{c}\text { Cari data } \\
\text { pasien } \\
\text { berdasarkan } \\
\text { nomor } \\
\text { Register }\end{array}$ & $\begin{array}{c}\text { Mengisi nomor } \\
\text { Register salah } \\
(0)\end{array}$ & $\begin{array}{c}\text { Sistem akan } \\
\text { menampilkan } \\
\text { "Data yang } \\
\text { anda cari tidak } \\
\text { ada" }\end{array}$ & $\begin{array}{c}\text { "Data yang } \\
\text { anda cari } \\
\text { tidak ada" }\end{array}$ & Valid \\
\hline 8 & $\begin{array}{c}\text { Cari data } \\
\text { pasien } \\
\text { berdasarkan } \\
\text { nomor } \\
\text { Register }\end{array}$ & $\begin{array}{c}\text { Mengisi no } \\
\text { Register benar }\end{array}$ & $\begin{array}{c}\text { Sistem akan } \\
\text { menampilkan } \\
\text { data registrasi } \\
\text { berdasarkan } \\
\text { nomor Register }\end{array}$ & $\begin{array}{c}\text { Data } \\
\text { registrasi } \\
\text { berdasarkan } \\
\text { nomor } \\
\text { Register }\end{array}$ & Valid \\
\hline
\end{tabular}

\section{Maintenance}

Maintenance yang diharapkan agar sistem dapat berjalan baik terdiri dari hardware dan software.

A. Spesifikasi hardware yang diperlukan adalah sebagai berikut:
a) Operating System : Windows 7
b) Processor
c) Memory (RAM) : $1 \mathrm{~GB}$
d) Monitor
e) Harddisk
f) Keyboard
: SVGA Colour 15"
g) Mouse
: $160 \mathrm{~GB}$
h) Printer
$107 \mathrm{Key}$
: Standard Mouse
: Deskjet

Spesifikasi software yang diperlukan adalah sebagai berikut:
a) Operating System : Windows Server 2000
b) Software
: Microsoft Visual Studio 2015
c) Bahasa Program : VB .NET
d) Database Server : Microsoft SQL Server 2012

\section{Kesimpulan}

Sistem komputerisasi untuk RSIJPK dapat mengatasi masalah antrian pendaftaran pasien BPJS dan pengelolaan data menjadi lebih mudah khususnya untuk pencarian data pasien dan pembuatan laporan. Dengan penerapan sistem ini proses antrian pasien menjadi lebih singkat sehingga memudahkan pasien untuk segera berkonsultasi dengan dokter yang diharapkan.

\section{DAFTAR PUSTAKA}

Hidayatullah, P. (2014). Visual Basic.Net Membuat Aplikasi Database dan Program Kreatif. Bandung: Informatika. 
Lemantara, S., \& Indrawati. (2015). Rancang Bangun Aplikasi Pencatatan Rekam Medis Pada Unit Rawat Jalan di Rumah Sakit Assakinah Medika Sidoarjo. JSIKA Vol. 4, No.2 September 2015, 1-6.

Nugroho , A. (2010). Rekayasa Perangkat Lunak Berorientasi Objek dengan Metode USDP. Yogyakarta: Andi.

Pratama, I. (2014). Sistem Informasi Dan Implementasinya. Bandung: Informatika Bandung.

Rizky, S. (2011). Konsep Dasar Rekayasa Perangkat Lunak Jakarta. Jakarta: Prestasi PustakaKarya.

Sutabri, T. (2012). Analisis Sistem Informasi. Yogyakarta: Andi Offset.

Triwahyuni. (2013). Pembangunan Sistem Informasi Rawat Jalan. Jurnal Informatika Vol. 13, No. 2 Desember $2013,160-168$

Widodo, P. P., \& Herlawati. (2011). Menggunakan UML. Bandung: Informatika Bandung.
Profile penulis

Fernando B Siahaan. Jakarta, 15 Februari 1971. Pada Tahun 1997 mendapatkan gelar S.Kom pada Jurusan Teknik Informatika Universitas Kristen Duta Wacana Yogyakarta, kemudian pada tahun 2011 mendapatkan gelar M.Kom pada Jurusan Ilmu Komputer STMIK NUSA MANDIRI, bekerja di AMIK BSI Jakarta sebagai Staff Akademik. Adapun tulisan yang pernah dipublikasikan antara lain:

[1] 1. Analisa Pengaruh Gaya Kepemimpinan dan Komunikasi Terhadap Kinerja Karyawan menggunakan Metode Fuzzy Inference System Pada PT. Bhanda Ghara Reksa di terbitkan pada Jurnal Teknik Komputer tahun 2017.

[2] 2. Sistem Informasi Penjualan Berbasis Web menggunakan Metode Virtual Account pada Seminar Nasional Ilmu Pengetahuan dan Teknologi Komputer (SNIPTEK) Tahun 2015.

[3] 3. Encryption - Decryption Program Design Using Substitusion And Gray Code Pada Seminar Internasional Tahun 2014

[4] 4. Perancangan Sistem Informasi Dealer Mobil Sinar Mutiara Motor Berbasis Web pada Konferensi Nasional Ilmu Sosial \& Teknologi (KNIST) 2013

[5] 5. Analisa Perancangan Strategi SI/TI menggunakan Metode Ward and Peppard Pada PT. Bumimas Megahprima pada Seminar Nasiona Informasi dan Teknologi (SNIT) 2012

6. Konsep E-Learning dalam mendukung Pembelajaran di Perguruan Tinggi pada Jurnal Cakrawala tahun 2012

Dede Awalludin. lahir di Karawang, 7 April 1981. Mendapatkan gelar Ahli Madya (A.Md) pada jurusan Manajemen Informatika di AMIK BSI Jakarta dan melanjutkan Strata satu (S. Kom) pada jurusan Sistem Informasi STMIK Nusa Mandiri pada tahun 2017. 